\title{
Antimicrobial properties of L-amino acid oxidase: biochemical features and biomedical applications
}

\author{
Kosuke Kasai ${ }^{1} \cdot$ Manabu Nakano ${ }^{1} \cdot$ Masami Ohishi $^{2} \cdot$ Toshiya Nakamura $^{1} \cdot$ Tomisato Miura $^{3}$
}

Received: 11 March 2021 / Revised: 17 May 2021 / Accepted: 28 May 2021 / Published online: 9 June 2021

(C) The Author(s), under exclusive licence to Springer-Verlag GmbH Germany, part of Springer Nature 2021

\begin{abstract}
Mucus layer that covers the body surface of various animal functions as a defense barrier against microbes, environmental xenobiotics, and predators. Previous studies have reported that L-amino acid oxidase (LAAO), present in several animal fluids, has potent properties against pathogenic bacteria, viruses, and parasites. LAAO catalyzes the oxidative deamination of specific Lamino acids with the generation of hydrogen peroxide and L-amino acid metabolites. Further, the generated hydrogen peroxide is involved in oxidation (direct effect) while the metabolites activate immune responses (indirect effect). Therefore, LAAO exhibits two different mechanisms of bioactivation. Previously, we described the selective, specific, and local oxidative and potent antibacterial actions of various LAAOs as potential therapeutic strategies. In this review, we focus on their biochemical features, enzymatic regulations, and biomedical applications with a view of describing their probable role as biochemical agents and biomarkers for microbial infections, cancer, and autoimmune-mediated diseases. We consider that LAAOs hold implications in biomedicine owing to their antimicrobial activity wherein they can be used in treatment of infectious diseases and as diagnostic biomarkers in the above-mentioned diseased conditions.
\end{abstract}

\section{Key points}

-Focus on biochemical features, enzymatic regulation, and biomedical applications of LAAOS.

- Mechanisms of antimicrobial activity, inflammatory regulation, and immune responses of LAAOs.

-Potential biomedical application as an antimicrobial and anti-infection agent, and disease biomarker.

Keywords Antimicrobial protein $\cdot \mathrm{L}$-amino acid oxidase $\cdot$ Interleukin (IL)-4-induced gene $1 \cdot$ Hydrogen peroxide $\cdot$ Metabolites $\cdot$ Biomarker

\section{Introduction}

L-amino acid oxidase (LAAO; EC: 1.4.3.2) is a flavoenzyme that catalyzes the oxidative deamination of an L-amino acid to an $\alpha$-keto acid with the generation of ammonia and hydrogen peroxide (Wellner and Meister 1961). Previously, we

Tomisato Miura

tomisato@hirosaki-u.ac.jp

1 Department of Biomedical Sciences, Division of Medical Life Sciences, Graduate School of Health Sciences, Hirosaki University, 66-1, Hon-cho, 036-8564, Hirosaki, Aomori, Japan

2 Snowden Co., Ltd., Tokyo, Japan

3 Department of Risk Analysis and Biodosimetry, Institute of Radiation Emergency Medicine, Hirosaki University, 66-1, Hon-cho, 036-8564, Hirosaki, Aomori, Japan described the bioactivities of LAAOs, including their antibacterial activity (Kasai et al. 2015b) that can be inhibited by catalases, suggesting that their antibacterial potential is due to the hydrogen peroxide produced during the reaction.

Hydrogen peroxide is a powerful oxidizing agent that acts as an intracellular signaling molecule and is involved in the oxidative bursts of phagocytes, thereby leading to the elimination of invading microorganisms (Clifford and Repine 1982). Briefly, hydrogen peroxide is an antimicrobial agent that induces DNA damage and cell death and is attributed to direct cytotoxicity and generation of reactive oxygen species (ROS) (Ueda and Shah 1992). This molecule regulates cell proliferation, growth arrest, apoptosis, and necrosis in various organisms (Vatansever et al. 2013). Owing to their diverse properties, LAAOs hold potential applications in detection and treatment of several diseased conditions, such as microbial infections, cancer, and autoimmune diseases. In this review, 
we have elaborated the biochemistry of LAAOs and focused on their potential applications in the field of biomedicine. This comprehensive overview of the current state of the LAAOs studies may facilitate the development of novel strategies for the diseased conditions.

\section{Biochemical features of LAAOs and their mechanism of action}

LAAOs are found in various animal fluids, including serum, snake venom, sea hare ink, body surface mucus of the snail and fish, mammary milk, and tissue extracts (mammary gland, intestine, liver, and kidney). Reportedly, several LAAOs have characteristic functions and excellent bioactivity in various species (Table 1). Further, Fig. 1 illustrates the molecular phylogenetic tree of LAAOs from various organisms. LAAOs are involved in innate immunity with selective and specific antibacterial properties (Kasai et al. 2015a (Table 1 V1), Kasai et al. 2015b (Table 1 V1), Teixeira et al. 2016 (Table 1 M2), Lazo et al. 2017 (Table $1 \mathrm{G}$ ), Rey-Suárez et al. 2018 (Table 1 N), Salama et al. 2018 (Table 1 L), Elsheimer-Matulova et al. 2020 (Table 1 D), Soares et al. 2020 (Table 1 E)), antiparasites (Carone et al. 2017 (Table 1 H2), Wiezel et al. 2019 (Table 1 M1), Soares et al. 2020 (Table 1 E), Barbosa et al. 2021) and induce DNA fragmentation (Mukherjee et al. 2015, Burin et al. 2016a, 2016b, Machado et al. 2018 (Table 1 H2), Machado et al. 2019a, 2019b (Table 1 H2)), apoptosis (Mukherjee et al. 2015, Fung et al. 2015 (Table 1 O), Burin et al. 2016a, 2016b, Ribeiro et al. 2016, Tan et al. 2017, Carone et al. 2017 (Table 1 H2), Machado et al. 2018 (Table 1 H2), Mukherjee et al. 2018, Rey-Suárez et al. 2018 (Table $1 \mathrm{~N}$ ), Bedoya-Medina et al. 2019 (Table $1 \mathrm{~N}$ )), regulation of immune responses (Cousin et al. 2015, Scarlata et al. 2015, Romagnani 2016, Bod et al. 2018, Ramspott et al. 2018 (Table 1 A), Aubatin et al. 2018 (Table 1 A), ElsheimerMatulova et al. 2020 (Table 1 D), Sadik et al. 2020), and cell cycle arrest (de Melo Alves Paiva et al. 2011 (Table 1 F), Machado et al. 2019a, 2019b (Table 1 H2)).

The mechanism of LAAOs' antibacterial action has been investigated extensively and the most prevalent mechanism is via generation of hydrogen peroxide, as described above. An early report showed that LAAO isolated from Crotalus adamanteus venom to be effective against bacteria (Skarnes 1970). Many previous reports have highlighted that the bactericidal activity of LAAOs is generally inhibited by catalases (Stiles et al. 1991, Stábeli et al. 2007, Nagashima et al. 2009 (Table 1 U), Kasai et al. 2015a (Table 1 V1), Soares et al. 2020 (Table $1 \mathrm{E})$ ), thereby the antibacterial action of LAAOs is due to the generated hydrogen peroxide.

Mammalian LAAO, which is capable of generating ROS upon exposure to an aromatic and hydrophobic amino acid, such as L-Trp or L-Phe in the presence of oxygen, has been found in milk (cow, donkey, and mouse), expressed immune cells (human, mouse, and chicken). Mammalian LAAO, which has an immunoregulatory function, was first detected in murine B cells (Chu and Paul 1997) and has been known to inhibit $\mathrm{T}$ cell proliferation (Boulland et al. 2007), cytotoxicity, and IFN- $\gamma$ production by tumor-infiltrating $\mathrm{CD} 8^{+} \mathrm{T}$ cells, which favors tumor escape. Human LAAO, encoded by interleukin (IL)-4-induced gene 1 (IL4I1), is secreted and expressed by macrophages $(\mathrm{M} \varphi)$ and dendritic cells (DCs) stimulated by microbial-derived products or interferons, which are endowed with immunoregulatory properties, and block the growth of gram-negative Escherichia coli and gram-positive Staphylococcus aureus (Puiffe et al. 2013).

Interestingly, I14I1 is found in the mammalian spermatozoa head (human, equine, and bovine), particularly in the acrosomal. The aromatic amino acids were substrates for equine sperm LAAO, eliciting the dose- and time-dependent generation of ROS via mechanisms that were enhanced by cell death (Aitken et al. 2015). The combination of aromatic amino acids and nonviable cells was also found to enhance the levels of lipid peroxidation in live spermatozoa. Houston et al. (Table 1 A) reported that the stimulation of LAAO activity results in the induction of several hallmarks of capacitation, including tyrosine phosphorylation of the sperm flagellum and concomitant activation of phospho-SRC expression, that are important in the regulation of growth and differentiation of eukaryotic cells (2015). In addition, stimulation of IL4I1 resulted in an increase in the levels of acrosomal exocytosis in both the presence and absence of progesterone stimulation via a mechanism that could be significantly reversed by the presence of catalase. Their results suggested that the existence of human spermatozoan LAAO has a potential role in driving the redox regulation of sperm capacitation and acrosomal exocytosis (Houston et al. 2015 (Table $1 \mathrm{~A})$ ).

On the contrary, mice have two isoforms of LAAO encoded by Laol or Il4il that are localized and expressed in lactating mammary glands during the lactation period and immune cells by microbial-derived products or interferons, respectively, similar to humans. LAO1 present in milk protects against bacterial infections by producing hydrogen peroxide (Sun et al. 2002 (Table 1 C), Nagaoka et al. 2009 (Table $1 \mathrm{C})$ ). Recently, gut microbiota profiles were compared between wild type and Laol-knockout mouse pups to determine whether LAO1 affects infant gut microbiota development via mother's milk consumption (Shigeno et al. 2019). In particular, the gut microbiota of lactating Laol-knockout pups was highly diverse, whereas those of the wild type were composed of only a few dominant bacteria, such as Lactobacillus sps. Furthermore, cross-fostering indicated that milk of wild type mothers has the ability to suppress this diversity in Lao 1-knockout pups. Moreover, the stomach contents of pups fed milk containing LAO1 could produce hydrogen peroxide. They suggested that hydrogen peroxide is 


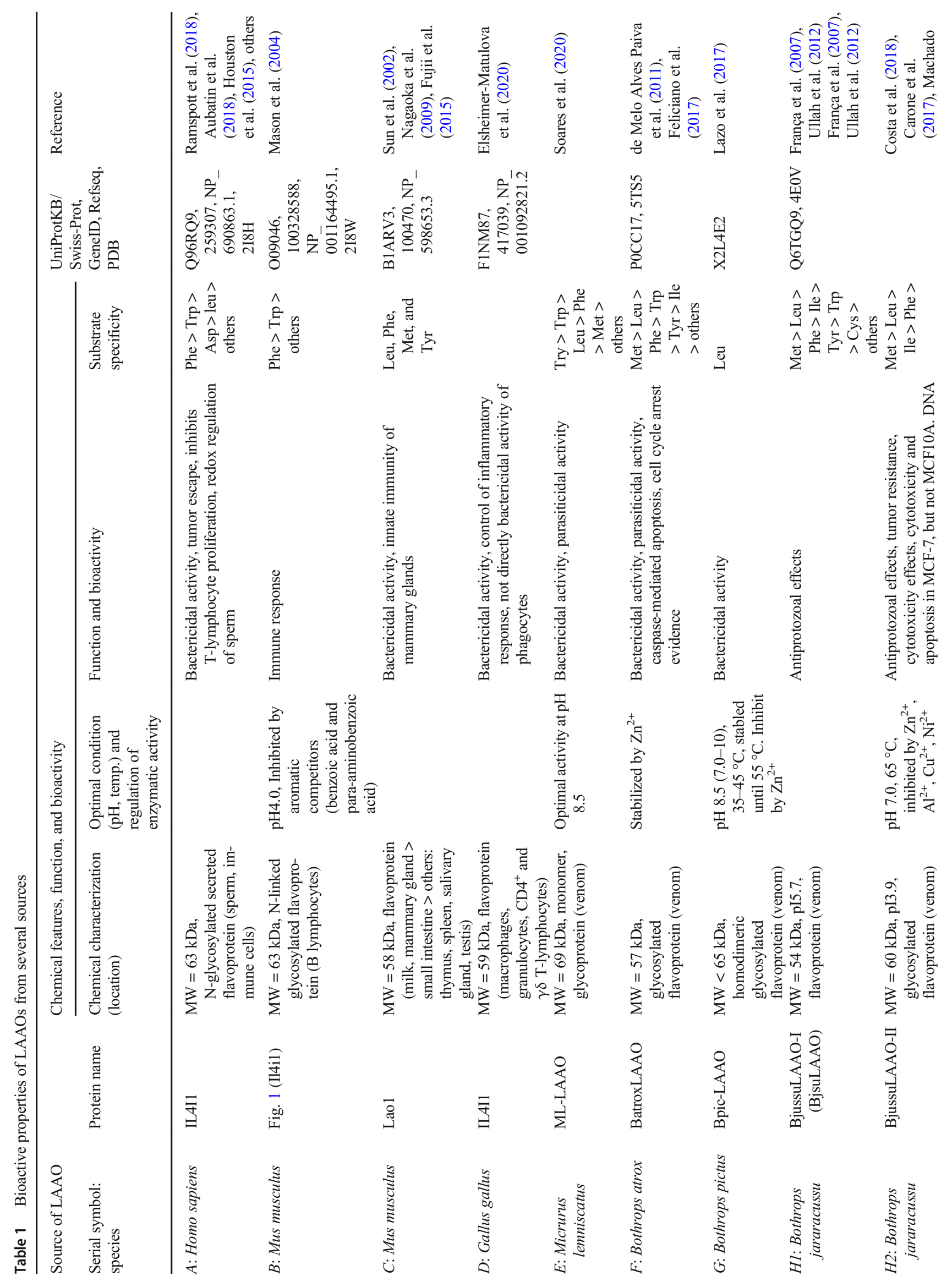




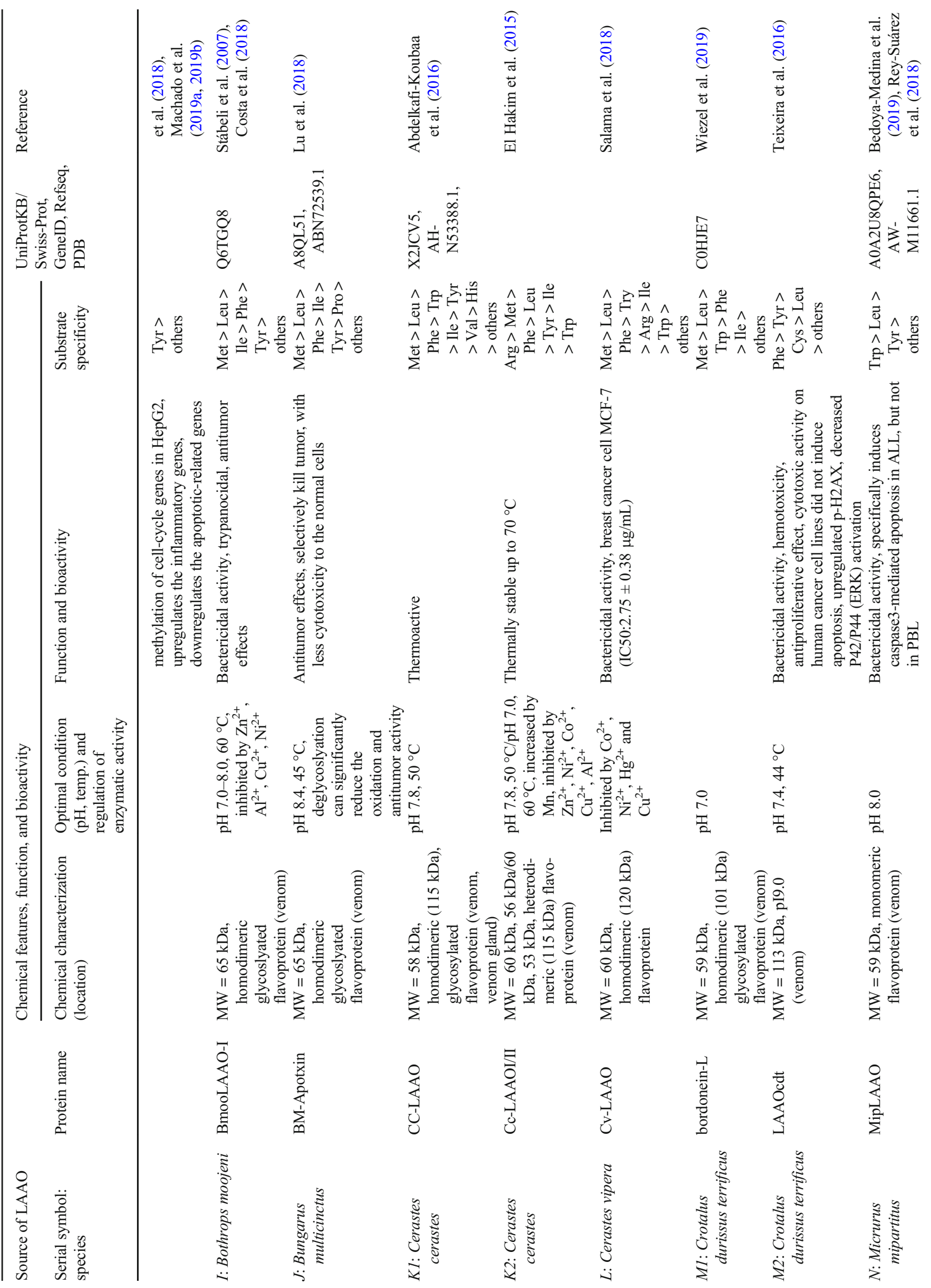




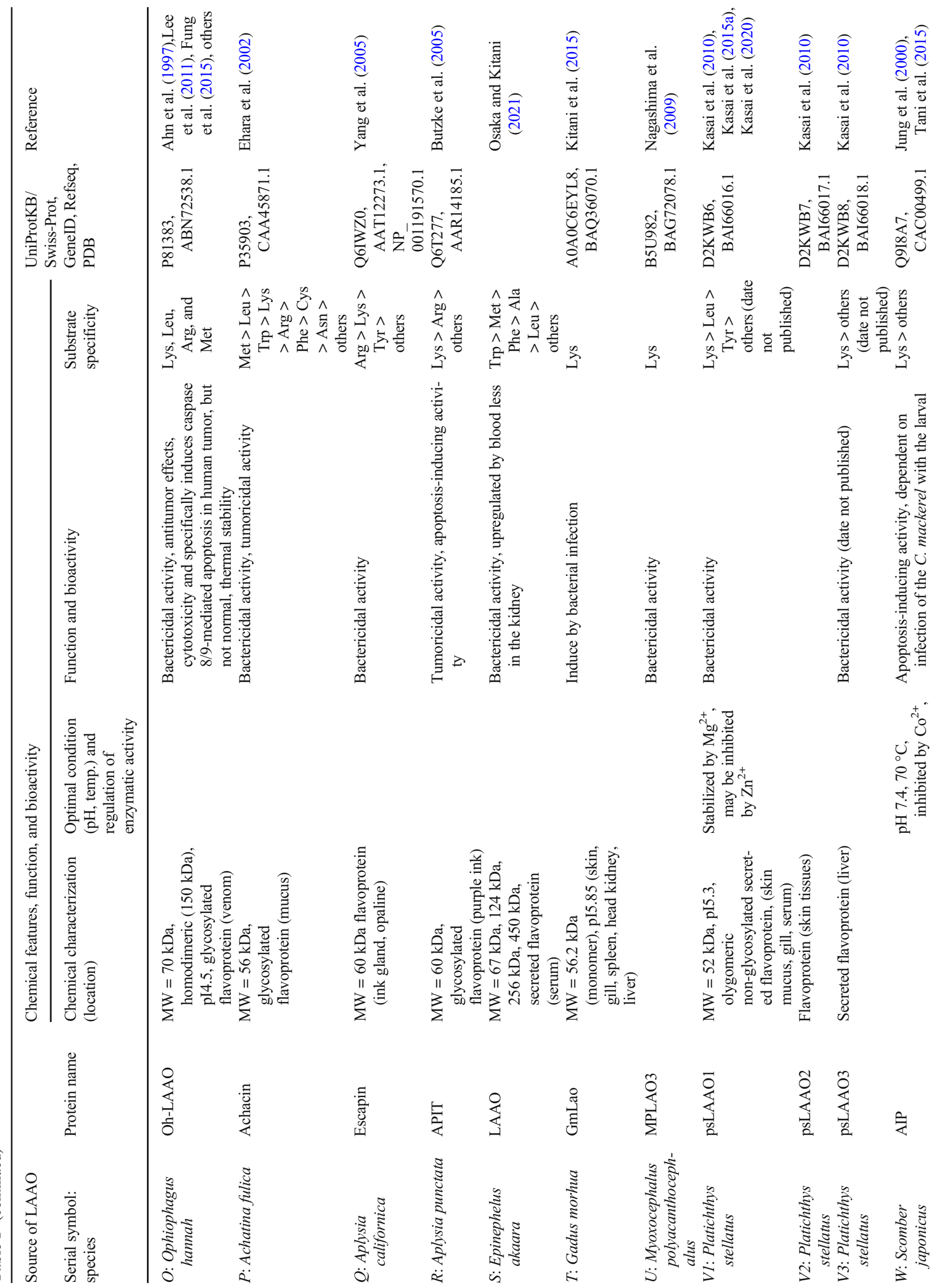




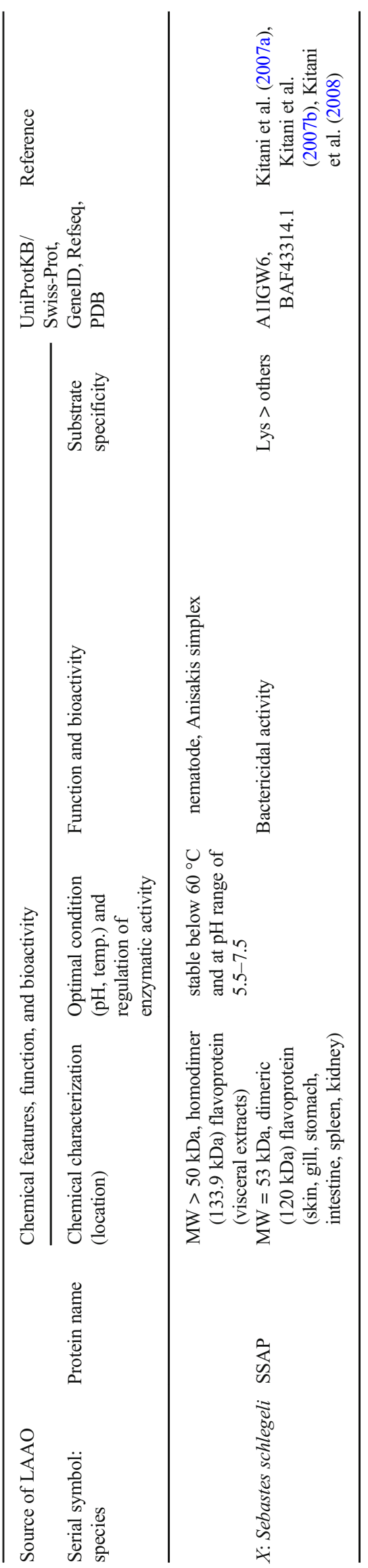


Fig. 1 Phylogenetic tree of $L A A O$ from different vertebrates. The tree is constructed by neighborjoining (NJ) method using $L A A O$ sequences with the bootstrap values indicated (1000 replicates). Bootstrap values $(\geq 50)$ are shown on the branch points. Scale bar represents 0.1 nucleotide substitutions per site

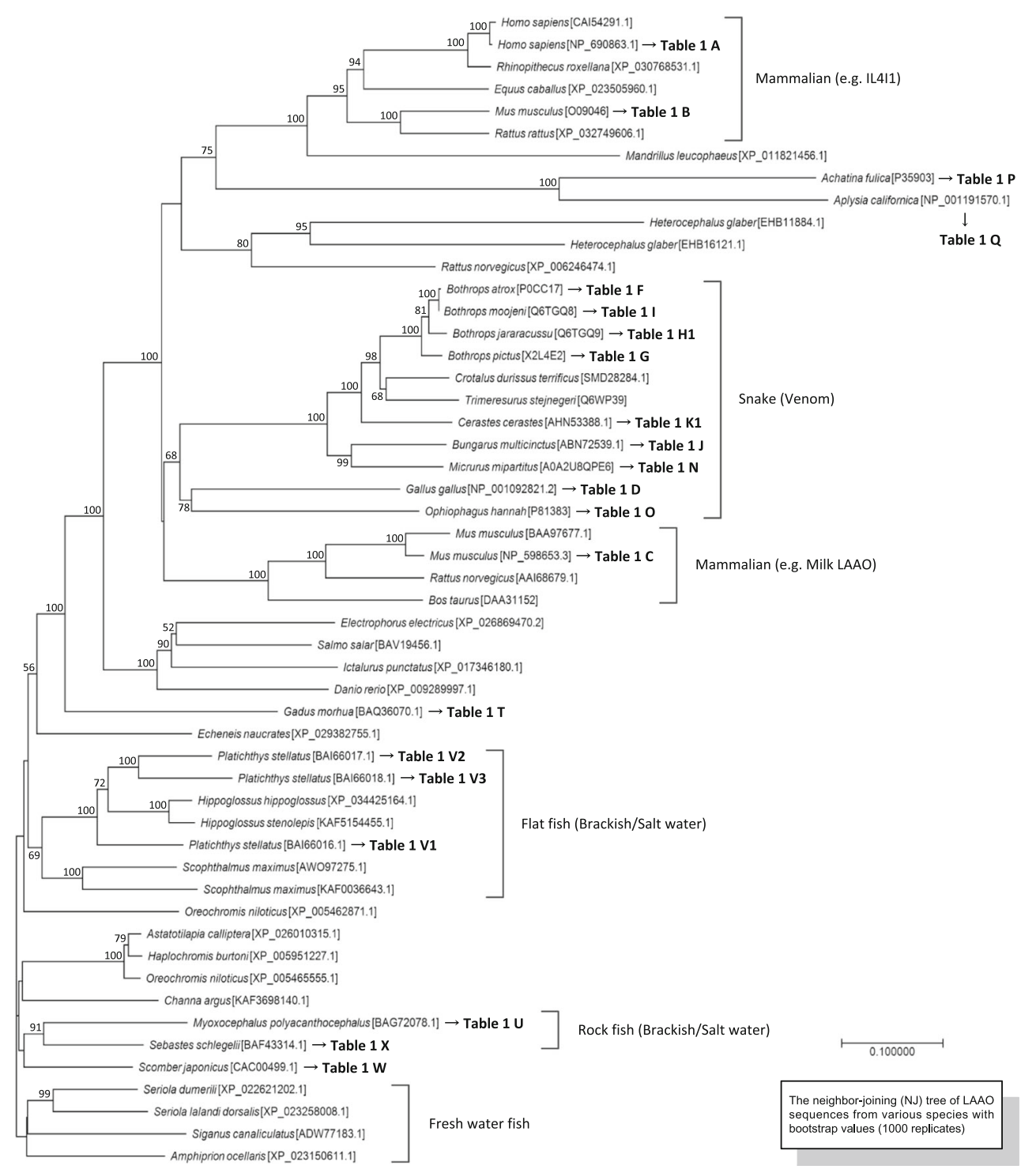

generated from the process of free amino acid metabolism in the mother's milk and may play a key role in regulating initial acquisition and development of the gut microbiota. Conclusively, LAO1-containing milk protects organs from bacterial infection via innate immunity.

Snake LAAOs are a major component of their venom and exhibit bactericidal (Lazo et al. 2017 (Table 1 G), Salama et al. 2018 (Table 1 L), Rey-Suárez et al. 2018 (Table 1 N)), parasiticidal (Carone et al. 2017 (Table $1 \mathrm{H} 2$ ), Wiezel et al. 2019 (Table 1 M1), Barbosa et al. 2021), and anticancer effects through caspase activation (Fung et al. 2015 (Table 1 O), Mukherjee et al. 2015, Burin et al. 2016a, 2016b, Carone et al. 2017 (Table 1 H2), Tan et al. 2017, Mukherjee et al. 2018, Machado et al. 2018 (Table 1 H2)). CR-LAAO, isolated from Calloselasma rhodostoma venom, has antitumor potential and induces acute inflammatory responses similar to mammalian LAAO in vivo, with recruitment of neutrophils and release of IL- 6 , IL- $1 \beta$, leukotriene
B4 $\left(\mathrm{LTB}_{4}\right)$, and prostaglandin E2 $\left(\mathrm{PGE}_{2}\right)$. In vitro, IL-6 and IL- $1 \beta$ production by peritoneal macrophages stimulated by CR-LAAO was dependent on the activation of the Toll-like receptors, TLR2 and TLR4 (Costa et al. 2017). CR-LAAO and several other LAAOs promote apoptosis of tumor cells mediated by the release of hydrogen peroxide and activation of immune cells, resulting in oxidative stress and production of cytokines, such as IL- 6 and IL- $1 \beta$, which trigger a series of events, such as activation of caspase $(-8,-9$, and -3$)$ cascade, and modulate cell cycle delay or arrest in the G0/ G1 and S phases of tumor cells (Costa et al. 2017). Moreover, CR-LAAO alters regulation of apoptosis by modulating expression of miRNAs related to anti-apoptotic genes (Bid, Bim, Bcl-2, Cip-2, c-Flip, and Mcl-1) in BCR$\mathrm{ABL}^{+}$cells (Burin et al. 2016a). They suggested that CRLAAO is a potential tool for enhancing apoptosis-related miRNA expression in chronic myeloid leukemia therapy (Burin et al. 2016a; Burin et al. 2016b). 
Previously, we reported that $2.5 \mu \mathrm{g} / \mathrm{mL}$ of psLAAO1 isolated from the flounder Platichthys stellatus, which favors LLys as a substrate, produced approximately $2.7 \mathrm{mM}$ of hydrogen peroxide within $1 \mathrm{~h}$ in the bacterial culture media (Kasai et al. 2015a (Table $1 \mathrm{~V} 1)$ ). This result suggests that sufficient levels of hydrogen peroxide can be produced by the action of psLAAO1 during the early bacterial growth phase to kill the bacteria under liquid culture conditions. Interestingly, psLAAO1 and other LAAOs (Achacin, OH-LAAO, SSAP, and CC-LAAO) bind to the bacterial membrane, which leads to localized high concentrations of hydrogen peroxide and antibacterial action in or near the bacterial surface (Ehara et al. 2002 (Table 1 P), Lee et al. 2011, Kitani et al. 2008 (Table 1 X), Kasai et al. 2015a (Table 1 V1), AbdelkafiKoubaa et al. 2016). In summary, LAAOs selectively and specifically bind to sensitive bacteria and exhibit their antibacterial effect by exposing the cells to high, localized concentrations of hydrogen peroxide near the bacterial surface.

\section{Characterization, structural stability, and regulation by metal ions}

Recently, it has been reported that snake LAAOs have unique characteristics, namely, wide range of optimal $\mathrm{pH}$, resistance to high temperatures, and structural conformation for enzymatic stability via regulation by metal ions. LAAOs from the venom of Bothrops jararacussu (BjussuLAAO-II) and Bothrops moojeni (BmooLAAO-I) showed high enzymatic activity in a wide temperature range of 25 to $75^{\circ} \mathrm{C}$ with broad range $\mathrm{pH}$ and high optimum temperature (pH 6.0 to 9.0 at 65 ${ }^{\circ} \mathrm{C}$ and pH 5.5 to 9.5 at $60{ }^{\circ} \mathrm{C}$ ).

Metal ions $\left(\mathrm{Zn}^{2+}, \mathrm{Al}^{3+}, \mathrm{Cu}^{2+}\right.$, and $\left.\mathrm{Ni}^{2+}\right)$ negatively modulate the enzymatic activity of the aforementioned LAAOs (Costa et al. 2018 (Table 1 I)). A homodimeric Cv-LAAOI from the venom of Cerastes vipera has antibacterial, antiproliferative, and cytotoxic effects via extensive hydrogen peroxide production and optimum enzymatic activity on L-Leu at $50{ }^{\circ} \mathrm{C}$. Moreover, the enzymatic activity is enhanced by $\mathrm{Mn}^{2+}$, while $\mathrm{Cu}^{2+}, \mathrm{Hg}^{2+}, \mathrm{Ni}^{2+}$, and $\mathrm{Co}^{2+}$ have suppressive effects on the oxidative activity (Salama et al. 2018 (Table $1 \mathrm{~L}$ )). LAAO from Peruvian Bothrops pictus (Bpic-LAAO), which is a homodimeric glycoprotein, exhibited optimal activity at $\mathrm{pH} 8.5$ and remained stable up to $55^{\circ} \mathrm{C}$ (Lazo et al. 2017 (Table 1 $\mathrm{G})$ ). The kinetic activity of Bpic-LAAO was inhibited by $\mathrm{Zn}^{2+}$, while $\mathrm{Ca}^{2+}, \mathrm{Mg}^{2+}$, and $\mathrm{Mn}^{2+}$ ions induced no significant change. Furthermore, enzymatic activity of Cc-LAAOI and Cc-LAAOII, purified from Cerastes Tomato venom, was increased by $\mathrm{Mn}^{2+}$, while $\mathrm{Zn}^{2+}, \mathrm{Ni}^{2+}, \mathrm{Co}^{2+}, \mathrm{Cu}^{2+}$, and $\mathrm{Al}^{3+}$ ions markedly inhibited the activities of both isoforms. Notably, the optimal temperature of both enzymes remains stable up to $70{ }^{\circ} \mathrm{C}$ (El Hakim et al. 2015). They suggested that the thermoactivity of Cc-LAAO is related to the hydrogen bond between Ser73 and Gly70, which is an external loop consisting of residues 64-73 for contact with the FAD cofactor and might act as an energy barrier to adopt an optimal conformation for the catalytic activity. Therefore, the optimal temperature for Cc-LAAO can be surpassed at elevated temperatures. Moreover, the crystal structure and molecular dynamics simulations of LAAO from the venom of Bothrops atrox (BatroxLAAO) presented a dimeric arrangement that can be stabilized by $\mathrm{Zn}^{2+}$ (Feliciano et al. 2017 (Table $1 \mathrm{~F}$ )). These results suggest that metal coordination is critical for dimerization and eventually rendering effective catalytic activity.

We recently reported that psLAAO1 pre-treated with a chelating agent showed transiently increased antibacterial activity that was either decreased or diminished after one or two freeze-thaw cycles. Moreover, the mutant constructs of His 348 , whose position is predicted to be a metal coordination site by homology modeling simulation, did not show antibacterial activity or $\mathrm{Mg}^{2+}$ coordination (Kasai et al. 2020 (Table 1 $\mathrm{V} 1)$ ), indicating that $\mathrm{Mg}^{2+}$ coordination is essential for the enzymatic activity and structural stability of psLAAO1 at His348. Metal detection assay revealed that pre-chelated psLAAO1 did not detect $\mathrm{Zn}^{2+}$, whereas 1 mole of the wild type or mutant constructs (His348Ala and His209Ala) detected approximately 0.5 mole of $\mathrm{Zn}^{2+}$. These results suggest that $\mathrm{Zn}^{2+}$ does not coordinate with monomeric psLAAO1 and that the metal ion probably inhibits its enzymatic activity. Therefore, metal removal can potentially increase the enzymatic activity or vulnerability of LAAOs via changes in structural complex and conformation.

\section{Immunoregulatory responses mediated by LAAOs}

Human $\mathrm{M} \varphi$ and DCs are major producers of L-Phecatabolized IL4I1 under inflammatory conditions; B cells also express IL4I1 in response to NF- $\mathrm{KB}$-activating stimuli (Marquet et al. 2010). IL4I1 inhibits the proliferation of CD3-stimulated $\mathrm{T}$ cells with a similar effect on $\mathrm{CD}^{+}$and $\mathrm{CD} 8^{+} \mathrm{T}$ cells via mature DCs. Notably, IL4I1 exerts inhibitory effects via its oxidative activity; these effects are associated with a transient downregulation of $\mathrm{T}$ cell receptor zeta (TCR $\zeta$ ) expression (Boulland et al. 2007). According to another study, the expression of IL4I1 has been reported in Th17 cells and a subset of $\mathrm{FOXP}^{+}$regulatory $\mathrm{T}$ (Treg) to $\mathrm{Th} 17$ transdifferentiating cells under inflammatory conditions (Scarlata et al. 2015). Moreover, IL4I1 expression is restricted to cells that do not express Helios, a transcription factor that characterizes natural Treg (nTreg) cells, but Aiolos, which is involved in the differentiation of Th17 and induced Treg (iTreg) cells. Supposedly, the expression of IL4I1 in Th17 and iTreg cells may provide insights into approaches that 
aim to modulate the balance of these populations in different pathological conditions involving inflammation-mediated immunosuppression, such as rheumatoid arthritis, inflammatory bowel disease, and multiple sclerosis. In fact, previous reports have suggested that the human IL4I1 ortholog is located on chromosome 19q13.3-19q13.4 (Chavan et al. 2002) in a region that is a hot spot for autoimmune disease susceptibility in general, including rheumatoid arthritis, multiple sclerosis, insulin-dependent diabetes mellitus, and systemic lupus erythematosus (Mason et al. 2004 (Table 1 B)). Therefore, an alteration in expression of IL4I1 could contribute to autoimmune disease, and its expression screening is a potential biomarker of inflammation-mediated immunosuppression.

Recently, IL4I1, which uses L-Phe as well as L-Trp as a substrate, activates the aryl hydrocarbon receptor (AHR) through the generation of indole metabolites and kynurenic acid (KynA) (Sadik et al. 2020) where the latter constitutes an important endogenous AHR ligand (Platten et al. 2019). In humans, L-Trp catabolism is initiated by indole-amine-2,3dioxygenase 1/2 (IDO1/2) or tryptophan-2,3-dioxgenase (TDO2). Cancers express high levels of IDO1 and TDO2, taking advantage of L-Trp catabolite-mediated AHR activation. The AHR-KynA axis enhances the malignant phenotype of cancer cells, particularly cancer cell motility. Moreover, AHR-KynA signaling suppresses $\mathrm{T}$ cell proliferation and function by inducing differentiation of Treg cells, expression of programmed cell death protein $1(\mathrm{PD} 1)$ on $\mathrm{CD} 8^{+} \mathrm{T}$ cells, and recruitment of immunosuppressive tumor-associated macrophages. These results suggest that IL4I1 promotes tumor progression as a metabolic consequence of immune checkpoints.

Recently, Elsheimer-Matulova et al. (Table 1 D) reported that IL4I1 from ISA brown chicken (Gallus gallus domesticus) is expressed in the cecum of newly hatched chickens 4 days post-infection with Salmonella enteritidis serovar Enteritidis. Moreover, chicken IL4I1 was expressed in $\mathrm{M} \varphi$, granulocytes, phagocytes, and $\mathrm{CD}^{+}$and $\gamma \delta \mathrm{T}$ cells, while they were not detected in $\mathrm{CD} 8^{+} \mathrm{T}$ or B cells (2020). Notably, mutation of the gene encoding chicken IL4I1 in M $\varphi$ HD11 did not affect the enzyme's bactericidal capacity against $S$. enteritidis ser. Enteritidis but negatively affected its oxidative burst after phorbol 12-myristate 13-acetate (PMA) stimulation. Their findings suggest that IL4I1 is not directly involved in the bactericidal activity of phagocytes but instead it is likely involved in the control of inflammatory responses and signaling to $\mathrm{T}$ and $\mathrm{B}$ cells.

In a recent study, an antibacterial LAAO from the serum of red-spotted grouper (Epinephelus akaara) showed a broad range of substrate specificity with aromatic and hydrophobic amino acids, similar to mammalian and snake LAAOs (Osaka and Kitani 2021 (Table $1 \mathrm{~S}$ )). Interestingly, the encoding gene was expressed at a low level in the kidney under normal conditions, while it was significantly upregulated by blood loss.
On the contrary, Il4il-knockout mice been exhibit an accelerated $\mathrm{B}$ cell egress from the bone marrow, resulting in the accumulation of peripheral follicular B cells (Bod et al. 2018) and present a higher serum level of natural immunoglobulins and self-reactive antibodies. Collectively, several LAAOs including IL4I1 may function as extreme responses and vicious circles of inflammation due to bacterial and viral infection in the peripheral or tissue environments, such as bacillemia, ischemic disease, and sepsis. These LAAOs prefer aromatic and hydrophobic amino acids for substrate specificity and are conserved in vertebrates through the process of evolution (Fig. 1).

\section{Perspectives for possible biomedical applications}

Previously, we reported that LAAOs have bioactive potential; they can produce hydrogen peroxide and can be used for developing drugs against community and health care-associated bacterial infections. Briefly, LAAOs show significant antibacterial activity against various pathogenic bacteria such as E. coli, Pseudomonas aeruginosa, Acinetobacter baumannii, Klebsiella pneumonia, Proteus mirabilis, Vibrio cholera, Yersinia enterocolitica, S. aureus, S. epidermidis, Enterococcus faecalis, and Streptococcus pyogenes that cause infections such as that of the urinary tract, bloodstream, and abdominal cavity, diarrhea, vomiting, intestinal inflammation, endocarditis, tympanitis, and conjunctivitis (Kasai et al. 2015b (Table $1 \mathrm{~V} 1)$ ).

Several studies have reported procedures for the production of recombinant LAAOs. For instance, fungal LAAO from Rhizoctonia solani (RsLAAO1) was expressed in E. coli BL21 Codon Plus (DE3) as a fusion protein with maltosebinding protein to induce solubility (Hahn et al. 2017a; Hahn et al. 2017b). Further, hcLAAO4, one of the fungal LAAOs from Hebeloma cylindrosporum, was expressed in E. coli or yeast (Pichia pastors) systems with His-Tag (Bloess et al. 2019; Heß et al. 2020). Moreover, L-Lysspecific LAAO isolated from the Siganus pramin (serum) or Platichthys stellatus (gill), which is an innate immune protein with antibacterial activity, was codon optimized for expression in insect cells (Sf9) or P. pastoris expression systems (Han et al. 2020, Kasai et al. 2020 (Table 1 V1)). These recombinant LAAOs can be easily high mass-produced by scale-up and display strong bioactivity via bactericidal, parasiticidal, and apoptotic effects, and bind to the surface of bacteria, similar to native LAAOs, suggesting potential use of LAAOs against clinical pathogens. Moreover, L-Lys $\alpha$-oxidase (LysOX; EC: 1.4.3.14), a homodimeric flavoenzyme that has substrate specificity for L-Lys as the name suggests, was identified from Scomber japonicus as an apoptosis-inducing protein. This enzyme was used for L-pipecolic acid synthesis 
using an $E$. coli expression system that expressed both LysOX and $\Delta^{1}$-piperideine-2-carboxylate reductase (Tani et al. 2015 (Table $1 \mathrm{~W})$ ). L-pipecolic acid produced by the action of LysOX is a precursor of numerous natural and synthetic bioactive compounds that function as immunosuppressants, anticancer agents, and local anesthetics. Based on these findings, LysOX is being investigated as a new approach for the production of chemical intermediates or precursors.

L-Trp is not only important in protein synthesis but also as a precursor of various biologically active compounds via the kynurenine pathway, generating metabolites with crucial functions in neurotransmission and regulation of immune responses. Notably, the depletion of L-Trp facilitates tumor immune escape by inducing Treg cells and expression of inhibitory receptors IL3 and IL4 on DCs and downregulating T cell receptor $\zeta$-chain (TCR $\zeta$ ) in $\mathrm{CD}^{+} \mathrm{T}$ cells (Brenk et al. 2009). L-Trp catabolic products downstream of IDO1/2 and TDO2 regulate immune cell function and promote cancer progression by activating AHR (Gutiérrez-Vázquez and Quintana 2018). As mentioned above, IL4I1 is expressed in Th17 cells and a subset of Treg to Th17 transdifferentiating cells under inflammatory conditions. Therefore, profiling IL4I1 expression in immune cells is a probable biomarker of the inflammatory grade and stage.

Hydrogen peroxide is a widely used antimicrobial agent; its efficacy has been demonstrated in several human viruses, among which coronaviruses have been found to be sensitive (Dev Kumar et al. 2020). Recently, several chemical agents used for viral decontamination could effectively inactivate human coronaviruses by surface disinfection procedures using $62-71 \%$ ethanol, $0.1 \%$ sodium hypochlorite, or $0.5 \%$ hydrogen peroxide for $60 \mathrm{~s}$ (Kampf et al. 2020). Previously, we described the antiviral activity of LAAOs demonstrated by various studies (Kasai et al. 2015b (Table 1 V1)). For instance, LysOX from the fungus Trichoderma viride inhibited the reproduction of the type I herpes simplex virus (Lukasheva and Berezov 2002). Additionally, LysOX was heterologously expressed by Streptomyces lividans TK24 (Amano et al. 2015). The enzymatic properties of the purified recombinant LysOX, such as substrate specificity and thermal stability, are same as those of native LysOX. LAAO from venom of the Chinese green tree viper Trimeresurus stejnegeri (TSV-LAO) also displayed dose-dependent inhibition of HIV-1 infection and replication. Notably, in the presence of catalase, TSVLAO inhibited syncytium formation in a dose-dependent manner, whereas anti-HIV-1 activity was not observed with the exogenous addition of hydrogen peroxide (Zhang et al. 2003). These results suggest that the antiviral activity of TSV-LAO does not affect infected cells via generation of hydrogen peroxide but rather by intermediate product or substrate depletion. L-Lys excess is characterized by a significant increase in HIV-1 RNA copies in enriched peripheral blood mononuclear cell fractions of HIV-infected patients and the copy number did not increase after adding L-Lys with LysOX in the plasma samples (Butorov 2015). Therefore, we consider that LysOX is a suitable antiviral as well as antibacterial agent. However, optimization of high production and yield of bioactive recombinant LAAOs and regulation of their cytotoxicity need further research.

\section{Conclusions}

LAAOs show high potency and efficacy as treatment strategy for various diseases and as biomarkers of autoimmune diseases, tumor grade, and immune signaling responses. Selective, specific, and localized activities of LAAOs in the early response are the underlying reasons for their potential biomedical implications. Although we now know that the direct or indirect bioactivities of LAAOs are associated with the catabolism of specific substrates and the production of hydrogen peroxide, several aspects such as the regulation of their enzymatic activities and conformation, selective usage per substrate specificity, production of intermediate products, and immune regulatory mechanisms remain poorly understood. It is, therefore, imperative to channelize future research with a clinical approach rendering each LAAO as a therapeutic agent. Moreover, LAAOs for clinical therapy must not only fulfil improved in vivo production but also $\mathrm{pH}$ resistance, thermal stability, and regulated substrate specificity and immune responses. Elucidating the mechanisms of LAAO selectivity against bacterial infections and evaluating the enzyme's effects on resistance, cytotoxicity, and genotoxicity must also be characterized to fully realize the therapeutic potential of these enzymes for biomedical applications.

Author's contribution KK conceived the paper, reviewed the literature, and wrote the manuscript. MN, MO, TN, and TM participated in selecting literature data and in writing the manuscript.

\section{Declarations}

Ethical approval This article does not contain any studies with human participants or animals performed by any of the authors.

Conflict of interest The authors declare no competing interests.

\section{References}

Abdelkafi-Koubaa Z, Aissa I, Morjen M, Kharrat N, El Ayeb M, Gargouri Y, Srairi-Abid N, Marrakchi N (2016) Interaction of a snake venom L-amino acid oxidase with different cell types membrane. Int J Biol Macromol 82:757-764. https://doi.org/10.1016/j. ijbiomac.2015.09.065

Ahn MY, Lee BM, Kim YS (1997) Characterization and cytotoxicity of L-amino acid oxidase from the venom of king cobra (Ophiophagus 
hannah). Int J Biochem Cell Biol 29(6):911-919. https://doi.org/10. 1016/s1357-2725(97)00024-1

Aitken JB, Naumovski N, Curry B, Grupen CG, Gibb Z, Aitken RJ (2015) Characterization of an L-amino acid oxidase in equine spermatozoa. Biol Reprod 92(5):125. https://doi.org/10.1095/ biolreprod.114.126052

Amano M, Mizuguchi H, Sano T, Kondo H, Shinyashiki K, Inagaki J, Tamura T, Kawaguchi T, Kusakabe H, Imada K, Inagaki K (2015) Recombinant expression, molecular characterization and crystal structure of antitumor enzyme, L-lysine $\alpha$-oxidase from Trichoderma viride. J Biochem 157(6):549-559. https://doi.org/ 10.1093/jb/mvv012

Aubatin A, Sako N, Decrouy X, Donnadieu E, Molinier-Frenkel V, Castellano F (2018) IL4-induced gene 1 is secreted at the immune synapse and modulates TCR activation independently of its enzymatic activity. Eur J Immunol 48(1):106-119. https://doi.org/10. 1002/eji.201646769

Barbosa LG, Costa TR, Borges IP, Costa MS, Carneiro AC, Borges BC, Silva MJB, Amorim FG, Quinton L, Yoneyama KAG, de Melo RV, Sampaio SV, Rodrigues RS (2021) A comparative study on the leishmanicidal activity of the L-amino acid oxidases BjussuLAAO-II and BmooLAAO-II isolated from Brazilian Bothrops snake venoms. Int J Biol Macromol 167:267-278. https://doi.org/10.1016/j.ijbiomac.2020.11.146

Bedoya-Medina J, Mendivil-Perez M, Rey-Suarez P, Jimenez-Del-Rio M, Núñez V, Velez-Pardo C (2019) L-amino acid oxidase isolated from Micrurus mipartitus snake venom (MipLAAO) specifically induces apoptosis in acute lymphoblastic leukemia cells mostly via oxidative stress-dependent signaling mechanism. Int J Biol Macromol 134:1052-1062. https://doi.org/10.1016/j.ijbiomac. 2019.05.174

Bloess S, Beuel T, Krüger T, Sewald N, Dierks T, Fischer von Mollard G (2019) Expression, characterization, and site-specific covalent immobilization of an L-amino acid oxidase from the fungus Hebeloma cylindrosporum. Appl Microbiol Biotechnol 103(5):2229-2241. https://doi.org/10.1007/s00253-018-09609-7

Bod L, Douguet L, Auffray C, Lengagne R, Bekkat F, Rondeau E, Molinier-Frenkel V, Castellano F, Richard Y, Prévost-Blondel A (2018) IL-4-induced gene 1: a negative immune checkpoint controlling B cell differentiation and activation. J Immunol 200(3):10271038. https://doi.org/10.4049/jimmunol.1601609

Boulland ML, Marquet J, Molinier-Frenkel V, Möller P, Guiter C, Lasoudris F, Copie-Bergman C, Baia M, Gaulard P, Leroy K, Castellano F (2007) Human IL4I1 is a secreted L-phenylalanine oxidase expressed by mature dendritic cells that inhibits $\mathrm{T}$ lymphocyte proliferation. Blood 110(1):220-227. https://doi.org/ 10.1182/blood-2006-07-036210

Brenk M, Scheler M, Koch S, Neumann J, Takikawa O, Häcker G, Bieber T, von Bubnoff D (2009) Tryptophan deprivation induces inhibitory receptors ILT3 and ILT4 on dendritic cells favoring the induction of human CD4+CD25+ Foxp3+ T regulatory cells. J Immunol 183(1): 145-154. https://doi.org/10.4049/jimmunol.0803277

Burin SM, Berzoti-Coelho MG, Cominal JG, Ambrosio L, Torqueti MR, Sampaio SV, de Castro FA (2016a) The L-amino acid oxidase from Calloselasma rhodostoma snake venom modulates apoptomiRs expression in Bcr-Abl-positive cell lines. Toxicon 120:9-14. https:// doi.org/10.1016/j.toxicon.2016.07.008

Burin SM, Ghisla S, Ouchida AT, Aissa AF, Coelho MG, Costa TR, Marsola AP, Pinto-Simões B, Antunes LM, Curti C, Sampaio SV, de Castro FA (2016b) CR-LAAO antileukemic effect against Bcr$\mathrm{Abl}(+)$ cells is mediated by apoptosis and hydrogen peroxide. Int $\mathrm{J}$ Biol Macromol 86:309-320. https://doi.org/10.1016/j.ijbiomac. 2016.01.069

Butorov EV (2015) Influence of L-lysine amino acid on the HIV-1 RNA replication in vitro. Antivir Chem Chemother 24(1):39-46. https:// doi.org/10.1177/2040206614566582
Butzke D, Hurwitz R, Thiede B, Goedert S, Rudel T (2005) Cloning and biochemical characterization of APIT, a new l-amino acid oxidase from Aplysia punctata. Toxicon 46(5):479-489. https://doi.org/10. 1016/j.toxicon.20

Carone SEI, Costa TR, Burin SM, Cintra ACO, Zoccal KF, Bianchini FJ, Tucci LFF, Franco JJ, Torqueti MR, Faccioli LH, Albuquerque S, Castro FA, Sampaio SV (2017) A new 1-amino acid oxidase from Bothrops jararacussu snake venom: isolation, partial characterization, and assessment of pro-apoptotic and antiprotozoal activities. Int J Biol Macromol 103:25-35. https://doi.org/10.1016/j.ijbiomac. 2017.05.025

Chavan SS, Tian W, Hsueh K, Jawaheer D, Gregersen PK, Chu CC (2002) Characterization of the human homolog of the IL-4 induced gene-1 (Fig1). Biochim Biophys Acta 1576(1-2):70-80. https://doi. org/10.1016/s0167-4781(02)00295-6

Chu CC, Paul WE (1997) Fig1, an interleukin 4-induced mouse B cell gene isolated by cDNA representational difference analysis. Proc Natl Acad Sci U S A 94:2507-2512. https://doi.org/10.1073/pnas. 94.6.2507

Clifford DP, Repine JE (1982) Hydrogen peroxide mediated killing of bacteria. Mol Cell Biochem 49(3):143-149. https://doi.org/10.1007/ BF00231175

Costa TR, Menaldo DL, Zoccal KF, Burin SM, Aissa AF, Castro FA, Faccioli LH, Greggi Antunes LM, Sampaio SV (2017) CR-LAAO, an L-amino acid oxidase from Calloselasma rhodostoma venom, as a potential tool for developing novel immunotherapeutic strategies against cancer. Sci Rep 7:42673. https://doi.org/10.1038/srep42673

Costa TR, Carone SEI, Tucci LFF, Menaldo DL, Rosa-Garzon NG, Cabral H, Sampaio SV (2018) Kinetic investigations and stability studies of two Bothrops L-amino acid oxidases. J Venom Anim Toxins Incl Trop Dis 24:37. https://doi.org/10.1186/s40409-0180172-9

Cousin C, Aubatin A, Le Gouvello S, Apetoh L, Castellano F, MolinierFrenkel V (2015) The immunosuppressive enzyme IL4I1 promotes FoxP3(+) regulatory T lymphocyte differentiation. Eur J Immunol 45(6):1772-1782. https://doi.org/10.1002/eji.201445000

de Melo Alves Paiva R, de Freitas FR, Antonucci GA, Paiva HH, de Lourdes Pires Bianchi M, Rodrigues KC, Lucarini R, Caetano RC, Linhari Rodrigues Pietro RC, Martins $\mathrm{CH}$, de Albuquerque S, Sampaio SV (2011) Cell cycle arrest evidence, parasiticidal and bactericidal properties induced by L-amino acid oxidase from Bothrops atrox snake venom. Biochimie 93(5):941-947. https:// doi.org/10.1016/j.biochi.2011.01.009

Dev Kumar G, Mishra A, Dunn L, Townsend A, Oguadinma IC, Bright KR, Gerba CP (2020) Biocides and novel antimicrobial agents for the mitigation of coronaviruses. Front Microbiol 11:1351. https:// doi.org/10.3389/fmicb.2020.01351

Ehara T, Kitajima S, Kanzawa N, Tamiya T, Tsuchiya T (2002) Antimicrobial action of achacin is mediated by L-amino acid oxidase activity. FEBS Let 531(3):509-512. https://doi.org/10.1016/ S0014-5793(02)03608-6

El Hakim AE, Salama WH, Hamed MB, Ali AA, Ibrahim NM (2015) Heterodimeric 1-amino acid oxidase enzymes from Egyptian Cerastes cerastes venom: purification, biochemical characterization and partial amino acid sequencing. J Genet Eng Biotechnol 13(2): 165-176. https://doi.org/10.1016/j.jgeb.2015.09.003

Elsheimer-Matulova M, Polansky O, Seidlerova Z, Varmuzova K, Stepanova H, Fedr R, Rychlik I (2020) Interleukin 4 inducible 1 gene (IL4I1) is induced in chicken phagocytes by Salmonella Enteritidis infection. Vet Res 51(1):67. https://doi.org/10.1186/ s13567-020-00792-y

Feliciano PR, Rustiguel JK, Soares RO, Sampaio SV, Cristina Nonato M (2017) Crystal structure and molecular dynamics studies of L-amino acid oxidase from Bothrops atrox. Toxicon 128:50-59. https://doi. org/10.1016/j.toxicon.2017.01.017 
França SC, Kashima S, Roberto PG, Marins M, Ticli FK, Pereira JO, Astolfi-Filho S, Stábeli RG, Magro AJ, Fontes MR, Sampaio SV, Soares AM (2007) Molecular approaches for structural characterization of Bothrops L-amino acid oxidases with antiprotozoal activity: cDNA cloning, comparative sequence analysis, and molecular modeling. Biochem Biophys Res Commun 355(2):302-306. https:// doi.org/10.1016/j.bbrc.2006.12.217

Fujii K, Zhang H, Usuda K, Watanabe G, Nagaoka K (2015) Lactogenic hormone stimulation and epigenetic control of L-amino acid oxidase expression in lactating mammary glands. J Cell Physiol 230(11): 2755-2762. https://doi.org/10.1002/jcp.25000

Fung SY, Lee ML, Tan NH (2015) Molecular mechanism of cell death induced by king cobra (Ophiophagus hannah) venom 1-amino acid oxidase. Toxicon 96:38-45. https://doi.org/10.1016/j.toxicon.2015. 01.012

Gutiérrez-Vázquez C, Quintana FJ (2018) Regulation of the immune response by the aryl hydrocarbon receptor. Immunity 48(1):19-33. https://doi.org/10.1016/j.immuni.2017.12.012

Hahn K, Neumeister K, Mix A, Kottke T, Gröger H, Fischer von Mollard G (2017a) Recombinant expression and characterization of a Lamino acid oxidase from the fungus Rhizoctonia solani. Appl Microbiol Biotechnol 101(7):2853-2864. https://doi.org/10.1007/ s00253-016-8054-y

Hahn K, Hertle Y, Bloess S, Kottke T, Hellweg T, Fischer von Mollard G (2017b) Activation of recombinantly expressed 1-amino acid oxidase from Rhizoctonia solani by sodium dodecyl sulfate. Molecules 22(12):2272. https://doi.org/10.3390/ molecules 22122272

Han X, Huang Y, Hou Y, Dang H, Li R (2020) Recombinant expression and functional analysis of antimicrobial Siganus oramin L-amino acid oxidase using the Bac-to-Bac baculovirus expression system. Fish Shellfish Immunol 98:962-970. https://doi.org/10.1016/j.fsi. 2019.11.062

$\mathrm{He}$ MC, Bloess S, Risse JM, Friehs K, Fischer von Mollard G (2020) Recombinant expression of an 1-amino acid oxidase from the fungus Hebeloma cylindrosporum in Pichia pastoris including fermentation. Microbiologyopen 9(10):e1112. https://doi.org/10.1002/ mbo3.1112

Houston B, Curry B, Aitken RJ (2015) Human spermatozoa possess an IL4I1 1-amino acid oxidase with a potential role in sperm function. Reproduction 149(6):587-596. https://doi.org/10.1530/REP-140621

Jung SK, Mai A, Iwamoto M, Arizono N, Fujimoto D, Sakamaki K, Yonehara S (2000) Purification and cloning of an apoptosisinducing protein derived from fish infected with Anisakis simplex, a causative nematode of human anisakiasis. J Immunol 165(3): 1491-1497. https://doi.org/10.4049/jimmunol.165.3.1491

Kampf G, Todt D, Pfaender S, Steinmann E (2020) Persistence of coronaviruses on inanimate surfaces and their inactivation with biocidal agents. J Hosp Infect 104(3):246-251. https://doi.org/10.1016/ j.jhin.2020.01.022

Kasai K, Ishikawa T, Komata T, Fukuchi K, Chiba M, Nozaka H, Nakamura T, Sato T, Miura T (2010) Novel L-amino acid oxidase with antibacterial activity against methicillin-resistant Staphylococcus aureus isolated from epidermal mucus of the flounder Platichthys stellatus. FEBS J 277(2):453-465. https://doi.org/ 10.1111/j.1742-4658.2009.07497.x

Kasai K, Hashiguchi K, Takahashi H, Kasai A, Takeda S, Nakano M, Lshikawa T, Nakamura T, Miura T (2015a) Recombinant production and evaluation of an antibacterial $\mathrm{L}$-amino acid oxidase derived from flounder Platichthys stellatus. Appl Microbiol Biotechnol 99: 6693-6703. https://doi.org/10.1007/s00253-015-6428-1

Kasai K, Ishikawa T, Nakamura T, Miura T (2015b) Antibacterial properties of L-amino acid oxidase: mechanisms of action and perspectives for therapeutic applications. Appl Microbiol Biotechnol 99(19):7847-7857. https://doi.org/10.1007/s00253-015-6844-2
Kasai K, Ito Y, Nitta A, Ariyoshi K, Nakamura T, Miura T (2020) Metal coordination by L-amino acid oxidase derived from flounder Platichthys stellatus is structurally essential and regulates antibacterial activity. Appl Microbiol Biothechnol 104:9645-9654. https:// doi.org/10.1007/s00253-020-10914-3

Kitani Y, Mori T, Nagai H, Toyooka K, Ishizaki S, Shiomi K, Nagashima Y (2007a) Gene expression and distribution of antibacterial L-amino acid oxidase in the rockfish Sebastes schlegeli. Fish shellfish Immunol 23(6):1178-1186. https://doi.org/10.1016/j.fsi.2007.04. 005

Kitani Y, Tsukamoto C, Zhang G, Nagai H, Ishida M, Ishizaki S, Shimakura K, Shiomi K, Nagashima Y (2007b) Identification of an antibacterial protein as L-amino acid oxidase in the skin mucus of rockfish Sebastes schlegeli. FEBS J 274(1):125-136. https://doi. org/10.1111/j.1742-4658.2006.05570.x

Kitani Y, Kikuchi N, Zhang G, Ishizaki S, Shimakura K, Shiomi K, Nagashima Y (2008) Antibacterial action of L-amino acid oxidase from the skin mucus of rockfish Sebastes schlegelii. Comp Biochem Physiol B Biochem Mol Biol 149(2):394-400. https://doi.org/10. 1016/j.cbpb.2007.10.013

Kitani Y, Fernandes JM, Kiron V (2015) Identification of the Atlantic cod L-amino acid oxidase and its alterations following bacterial exposure. Dev Comp Immunol 50(2):116-120. https://doi.org/10.1016/j. dci.2015.02.007

Lazo F, Vivas-Ruiz DE, Sandoval GA, Rodríguez EF, Kozlova EEG, Costal-Oliveira F, Chávez-Olórtegui C, Severino R, Yarlequé A, Sanchez EF (2017) Biochemical, biological and molecular characterization of an L-Amino acid oxidase (LAAO) purified from Bothrops pictus Peruvian snake venom. Toxicon 139:74-86. https://doi.org/10.1016/j.toxicon.2017.10.001

Lee ML, Tan NH, Fung SY, Sekaran SD (2011) Antibacterial action of a heat-stable form of L-amino acid oxidase isolated from king cobra (Ophiophagus Hannah) venom. Comp Biochem Physiol C Toxicol Pharmacol 153(2):237-242. https://doi.org/10.1016/j.cbpc.2010.11. 001

Lu W, Hu L, Yang J, Sun X, Yan H, Liu J, Chen J, Cheng X, Zhou Q, Yu Y, Wei JF, Cao P (2018) Isolation and pharmacological characterization of a new cytotoxic L-amino acid oxidase from Bungarus multicinctus snake venom. J Ethnopharmacol 213:311-320. https://doi.org/10.1016/j.jep.2017.11.026

Lukasheva EV, Berezov TT (2002) L-Lysine $\alpha$-oxidase: physicochemical and biological properties. Biochemistry (Mosc) 10:1152-1158. https://doi.org/10.1023/a:1020967408229

Machado ART, Aissa AF, Ribeiro DL, Hernandes LC, Machado CS, Bianchi MLP, Sampaio SV, Antunes LMG (2018) The toxin BjussuLAAO-II induces oxidative stress and DNA damage, upregulates the inflammatory cytokine genes $T N F$ and $I L 6$, and downregulates the apoptotic-related genes $B A X, B C L 2$ and RELA in human Caco-2 cells. Int J Biol Macromol 109:212-219. https:// doi.org/10.1016/j.ijbiomac.2017.12.015

Machado ART, Aissa AF, Ribeiro DL, Costa TR, Ferreira RS Jr, Sampaio SV, Antunes LMG (2019a) Cytotoxic, genotoxic, and oxidative stress-inducing effect of an 1-amino acid oxidase isolated from Bothrops jararacussu venom in a co-culture model of HepG2 and HUVEC cells. Int J Biol Macromol 127:425-432. https://doi.org/10.1016/j.ijbiomac.2019.01.059

Machado ART, Aissa AF, Ribeiro DL, Ferreira RS Jr, Sampaio SV, Antunes LMG (2019b) BjussuLAAO-II induces cytotoxicity and alters DNA methylation of cell-cycle genes in monocultured/cocultured HepG2 cells. J Venom Anim Toxins Incl Trop Dis 25: e147618. https://doi.org/10.1590/1678-9199-JVATITD-1476-18

Marquet J, Lasoudris F, Cousin C, Puiffe ML, Martin-Garcia N, Baud V, Chereau F, Farcet JP, Molinier-Frenkel V, Castellano F (2010) Dichotomy between factors inducing the immunosuppressive enzyme IL-4-induced gene 1 (IL4I1) in B lymphocytes and 
mononuclear phagocytes. Eur J Immunol 40(9):2557-2568. https:// doi.org/10.1002/eji.201040428

Mason JM, Naidu MD, Barcia M, Porti D, Chavan SS, Chu CC (2004) IL-4-induced gene-1 is a leukocyte L-amino acid oxidase with an unusual acidic $\mathrm{pH}$ preference and lysosomal localization. J Immunol 173(7):4561-4567. https://doi.org/10.4049/jimmunol.173.7.4561

Mukherjee AK, Saviola AJ, Burns PD, Mackessy SP (2015) Apoptosis induction in human breast cancer (MCF-7) cells by a novel venom L-amino acid oxidase (Rusvinoxidase) is independent of its enzymatic activity and is accompanied by caspase- 7 activation and reactive oxygen species production. Apoptosis 20(10):1358-1372. https://doi.org/10.1007/s10495-015-1157-6

Mukherjee AK, Saviola AJ, Mackessy SP (2018) Cellular mechanism of resistance of human colorectal adenocarcinoma cells against apoptosis-induction by Russell's Viper venom 1-amino acid oxidase (Rusvinoxidase). Biochimie 150:8-15. https://doi.org/10.1016/j. biochi.2018.04.017

Nagaoka K, Aoki F, Hayashi M, Muroi Y, Sakurai T, Itoh K, Ikawa M, Okabe M, Imakawa K, Sakai S (2009) L-amino acid oxidase plays a crucial role in host defense in the mammary glands. FASEB J 23(8): 2514-2520. https://doi.org/10.1096/fj.08-126466

Nagashima Y, Tsukamoto C, Kitani Y, Ishizaki S, Nagai H, Yanagimoto $\mathrm{T}$ (2009) Isolation and cDNA cloning of an antibacterial L-amino acid oxidase from the skin mucus of the great sculpin Myoxocephalus polyacanthocephalus. Comp Biochem Physiol B Biochem Mol Biol 154(1):55-61. https://doi.org/10.1016/j.cbpb. 2009.05.006

Osaka Y, Kitani Y (2021) Blood loss induces l-amino acid oxidase gene expression in the head kidney of the red-spotted grouper, Epinephelus akaara. Dev Comp Immunol 114:103842. https://doi. org/10.1016/j.dci.2020.103842

Platten M, Nollen EAA, Röhrig UF, Fallarino F, Opitz CA (2019) Tryptophan metabolism as a common therapeutic target in cancer, neurodegeneration and beyond. Nat Rev Drug Discov 18(5):379 401. https://doi.org/10.1038/s41573-019-0016-5

Puiffe M-L, Lachaise I, Molinier-Frenkel V, Castellano F (2013) Antibacterial properties of the mammalian L-amino acid oxidase IL4I1. PLoS One 8(1):e54589. https://doi.org/10.1371/journal. pone.0054589

Ramspott JP, Bekkat F, Bod L, Favier M, Terris B, Salomon A, Djerroudi L, Zaenker KS, Richard Y, Molinier-Frenkel V, Castellano F, Avril MF, Prévost-Blondel A (2018) Emerging role of IL-4-induced gene 1 as a prognostic biomarker affecting the local T-cell response in human cutaneous melanoma. J Invest Dermatol 138(12):26252634. https://doi.org/10.1016/j.jid.2018.06.178

Rey-Suárez P, Acosta C, Torres U, Saldarriaga-Córdoba M, Lomonte B, Núñez V (2018) MipLAAO, a new L-amino acid oxidase from the redtail coral snake Micrurus mipartitus. PeerJ 6:e4924. https://doi. org/10.7717/peerj.4924

Ribeiro PH, Zuliani JP, Fernandes CF, Calderon LA, Stábeli RG, Nomizo A, Soares AM (2016) Mechanism of the cytotoxic effect of 1-amino acid oxidase isolated from Bothrops alternatus snake venom. Int J Biol Macromol 92:329-337. https://doi.org/10.1016/j.ijbiomac. 2016.07.022

Romagnani S (2016) IL4I1: key immunoregulator at a crossroads of divergent T-cell functions. Eur J Immunol 46(10):2302-2305. https://doi.org/10.1002/eji.201646617

Sadik A, Somarribas Patterson LF, Öztürk S, Mohapatra SR, Panitz V, Secker PF, Pfänder P, Loth S, Salem H, Prentzell MT, Berdel B, Iskar M, Faessler E, Reuter F, Kirst I, Kalter V, Foerster KI, Jäger E, Guevara CR, Sobeh M, Hielscher T, Poschet G, Reinhardt A, Hassel JC, Zapatka M, Hahn U, von Deimling A, Hopf C, Schlichting R, Escher BI, Burhenne J, Haefeli WE, Ishaque N, Böhme A, Schäuble S, Thedieck K, Trump S, Seiffert M, Opitz CA (2020) IL4I1 is a metabolic immune checkpoint that activates the AHR and promotes tumor progression. Cell 182:1252-1270.e34. https://doi.org/10. 1016/j.cell.2020.07.038

Salama WH, Ibrahim NM, El Hakim AE, Bassuiny RI, Mohamed MM, Mousa FM, Ali MM (2018) 1-Amino acid oxidase from Cerastes vipera snake venom: isolation, characterization and biological effects on bacteria and tumor cell lines. Toxicon 150:270-279. https://doi.org/10.1016/j.toxicon.2018.06.064

Scarlata CM, Celse C, Pignon P, Ayyoub M, Valmori D (2015) Differential expression of the immunosuppressive enzyme IL4I1 in human induced Aiolos+, but not natural Helios+, FOXP3+ Treg cells. Eur J Immunol 45(2):474-479. https://doi.org/10.1002/eji. 201444897

Shigeno Y, Zhang H, Banno T, Usuda K, Nochi T, Inoue R, Watanabe G, Jin W, Benno Y, Nagaoka K (2019) Gut microbiota development in mice is affected by hydrogen peroxide produced from amino acid metabolism during lactation. FASEB J 33(3):3343-3352. https:// doi.org/10.1096/fj.201801462R

Skarnes RC (1970) L-amino-acid oxidase, a bactericidal system. Nature 225(5237):1072-1073. https://doi.org/10.1038/2251072a0

Soares TG, Santos JLD, Alvarenga VG, Santos JSC, Leclercq SY, Faria CD, Oliveira MAA, Bemquerer MP, Sanchez EOF, de Lima ME, Figueiredo SG, Borges MH (2020) Biochemical and functional properties of a new l-amino acid oxidase (LAAO) from Micrurus lemniscatus snake venom. Int J Biol Macromol 154:1517-1527. https://doi.org/10.1016/j.ijbiomac.2019.11.033

Stábeli RG, Sant'Ana CD, Ribeiro PH, Costa TR, Ticli FK, Pires MG, Nomizo A, Albuquerque S, Malta-Neto NR, Marins M, Sampaio SV, Soares AM (2007) Cytotoxic L-amino acid oxidase from Bothrops moojeni: biochemical and functional characterization. Int J Biol Macromol 41(2):132-140. https://doi.org/10.1016/j.ijbiomac. 2007.01.006

Stiles BG, Sexton FW, Weinstein SA (1991) Antibacterial effects of different snake venoms: purification and characterization of antibacterial proteins from Pseudechis australis (Australian king brown or mulga snake) venom. Toxicon 29(9):1129-1141. https://doi.org/10. 1016/0041-0101(91)90210-i

Sun Y, Nonobe E, Kobayashi Y, Kuraishi T, Aoki F, Yamamoto K, Sakai S (2002) Characterization and expression of L-amino acid oxidase of mouse milk. J Biol Chem 277(21):19080-19086. https://doi.org/ 10.1074/jbc.M200936200

Tan KK, Ler SG, Gunaratne J, Bay BH, Ponnampalam G (2017) In vitro cytotoxicity of L-amino acid oxidase from the venom of Crotalus mitchellii pyrrhus. Toxicon 139:20-30. https://doi.org/10.1016/j. toxicon.2017.09.012

Tani Y, Omatsu K, Saito S, Miyake R, Kawabata H, Ueda M, Mihara H (2015) Heterologous expression of 1-lysine $\alpha$-oxidase from Scomber japonicus in Pichia pastoris and functional characterization of the recombinant enzyme. J Biochem 157(4):201-210. https://doi.org/ $10.1093 / \mathrm{jb} / \mathrm{mvu} 064$

Teixeira TL, Oliveira Silva VA, da Cunha DB, Polettini FL, Thomaz CD, Pianca AA, Zambom FL, da Silva Leitão Mazzi DP, Reis RM, Mazzi MV (2016) Isolation, characterization and screening of the in vitro cytotoxic activity of a novel L-amino acid oxidase (LAAOcdt) from Crotalus durissus terrificus venom on human cancer cell lines. Toxicon 119:203-217. https://doi.org/10.1016/j. toxicon.2016.06.009

Ueda N, Shah SV (1992) Endonuclease-induced DNA damage and cell death in oxidant injury to renal tubular epithelial cells. J Clin Invest 90(6):2593-2597. https://doi.org/10.1172/JCI1 16154

Ullah A, Souza TA, Abrego JR, Betzel C, Murakami MT, Arni RK (2012) Structural insights into selectivity and cofactor binding in snake venom L-amino acid oxidases. Biochem Biophys Res Commun 421(1):124-128. https://doi.org/10.1016/j.bbrc.2012.03. 129

Vatansever F, de Melo WC, Avci P, Vecchio D, Sadasivam M, Gupta A, Chandran R, Karimi M, Parizotto NA, Yin R, Tegos GP, Hamblin 
MR (2013) Antimicrobial strategies centered around reactive oxygen species-bactericidal antibiotics, photodynamic therapy, and beyond. FEMS Microbiol Rev 37(6):955-989. https://doi.org/10. 1111/1574-6976.12026

Wellner D, Meister A (1961) Studies on the mechanism of action of Lamino acid oxidase. J Biol Chem 236:2357-2364

Wiezel GA, Rustiguel JK, Morgenstern D, Zoccal KF, Faccioli LH, Nonato MC, Ueberheide B, Arantes EC (2019) Insights into the structure, function and stability of bordonein-L, the first L-amino acid oxidase from Crotalus durissus terrificus snake venom. Biochimie 163:33-49. https://doi.org/10.1016/j.biochi.2019.05.009

Yang H, Johnson PM, Ko KC, Kamio M, Germann MW, Derby CD, Tai PC (2005) Cloning, characterization and expression of escapin, a broadly antimicrobial FAD-containing L-amino acid oxidase from ink of the sea hare Aplysia californica. J Exp Biol 208(Pt 18):36093622. https://doi.org/10.1242/jeb.01795

Zhang YJ, Wang JH, Lee WH, Wang Q, Liu H, Zheng YT, Zhang Y (2003) Molecular characterization of Trimeresurus stejnegeri venom L-amino acid oxidase with potential anti-HIV activity. Biochem Biophys Res Commun 309:598-604. https://doi.org/10.1016/j.bbrc. 2003.08.044

Publisher's note Springer Nature remains neutral with regard to jurisdictional claims in published maps and institutional affiliations. 